Journal of Engineering and Applied Sciences 14 (Special Issue 3): 6077-6081, 2019

ISSN: 1816-949X

(C) Medwell Journals, 2019

\title{
Creating Green Campus for Happiness and Wellbeing
}

\author{
${ }^{1}$ Margaret Chan Kit Yok, ${ }^{2}$ Ling Siew Eng and ${ }^{1}$ Siti Sahmsiah Sahmat \\ ${ }^{1}$ Faculty of Plantation and Agrotechnology, Universiti Teknologi MARA, Sarawak Branch, Malaysia \\ drmchan@.Uitm.edu.my, sitis274@uitm.edu.my \\ ${ }^{2}$ Faculty of Computer and Mathematical Sciences, Universiti Teknologi MARA, \\ Sarawak Branch, Malaysia, lingse@uitm.edu.my
}

\begin{abstract}
When it comes to seeking happiness leading to a sense of wellbeing, good quality environment has been recognized as an important contributor. The community is expected to be more satisfied with their life and happier if they feel safe and secure in well kept, tidy and pleasant environment. Growing a green campus is a new frontier in many institutions in developing ecologically sustainable lifestyles, since, the Stockholm Declaration addressing the sustainability in higher education. In Goal 11 of the Sustainable Development Goals of United Nation emphasizing on making cities and human settlement inclusive, safe, resilient and sustainable, an environmental campus management is very important in sustaining the happiness and wellbeing of the community. A green campus management checklist on ecology-keeping factors on greening initiatives was conducted in three campuses of Universiti Teknologi MARA, Sarawak Branch to weigh the institution actions on the sustainability practices using SurveyMonkey to capture the response of the staff and students. The survey also included two questions that addressed the notion of subjective happiness and well-being. The first one asked respondents whether taking all things together, they were very happy, quite happy, not very happy or not at all happy. The second one asked participants, all things considered, how satisfied they were given a scale of 1-10 from which to choose their level of life satisfaction. This study reveals there were high level of involvement sustainability practices and its relation to happiness and wellbeing.
\end{abstract}

Key words: Happiness, wellbeing, green campus, ecologically sustainable lifestyles, ecology-keeping factors, SurveyMonkey

\section{INTRODUCTION}

Universiti Teknologi MARA (UiTM) is the Malaysia's largest institution of higher learning in terms of size and population of approximately 147,000 students and 17,617 staff and since, its inception in 1956 with 35 campuses and 21 affiliated colleges nationwide should ascribed to green campus landscape. UiTM recognises that it is a big challenge to find the best way to keep everyone happy and productive. It is for this reason UiTM Happiness Index was established in 2016. This was an initiative to identify and measure happiness among the staff to ensure the sustainability of their development by understanding the level of happiness in the workplace. Three broad accounts of ways to conceive happiness and wellbeing as stated by Dolan and Metcalfe (2012):

- Objective lists, in which wellbeing is the fulfilment of a fixed set of material, psychological and social needs, identified exogenously
- Preference satisfaction, the standard economic view, in which wellbeing, consists in the freedom and resources to meet one's own wants and desires

- Happiness and subjective wellbeing, in which wellbeing is measured by people's self-reports in response to appropriate questioning

When it comes to seeking happiness leading to a sense of wellbeing, good quality environment has been recognized as an important contributor. The community is expected to be more satisfied with their life and happier if they feel safe and secure in well kept, tidy and pleasant environment. Thus, Goal 11 of the Sustainable Development Goals of United Nation emphasizes on making cities and human settlement inclusive, safe, resilient and sustainable (Anonymous, 2015). An environmental campus management is very important in sustaining the happiness and wellbeing of the community. Growing a green campus is a new frontier in many institutions in developing ecologically sustainable

Corresponding Author: Margaret Chan Kit Yok, Faculty of Plantation and Agrotechnology, Universiti Teknologi MARA, Sarawak Branch, Malaysia, drmchan@.Uitm.edu.my 
lifestyles. The Stockholm Declaration of 1972 addressed the Sustainability in Higher Education(SHE) (Handl, 2012) as summarized by Tiyarattanachai and Hollmann (2016) with the focus on finding ways in which universities, their leaders, lecturers, researchers and students can engage their resources in responding to the challenges of balancing between human quest for economic and technological development with environmental preservation. Before the declaration of SHE, Alshuwaikhat and Abubakar (2008) commented that environmental issues received little or no attention with the main focus on the importance of research and academic education. Since, then the green campus initiatives have significantly gained momentum (Grindsted and Holm, 2012). As MacKerron and Mourato (2013) stated, there was sufficient evidence from their study that happiness is greater in natural environment. Green campus is a concept to build sustainable living practices that are environmentally friendly in educational institutions around the world (Sisriany and Fatimah, 2017). According to Knight and Tsuchiya (n.d.), living in a greener environment will make one happier. In addition Escobar-Tello and Bhamra (2013) stated that happiness is a harmonising path for bringing higher education towards sustainability.

In 2010, the Universitas Indonesia (UI) GreenMetric World University Ranking was established as a platform for universities around the world to share their information and practices to achieve sustainability in their campuses (Suwartha and Sari, 2013). Six main categories were used as indicators that include setting and infrastructure, energy and climate change, waste management, water usage, transportation and environmental education. Thus, the purposes of this study were: to analyse green campus implementation in UiTM Sarawak Branch and to study how the students perceived green campus landscape and its relation to wellbeing and happiness.

\section{MATERIALS AND METHODS}

A green campus management checklist on ecology-keeping factors on greening initiatives was adapted from reconciliation with creation, Jesuit CAP Task Force on Ecology. The self-reporting response from the three administrative heads of the three campuses: Samarahan campus, Samarahan 2 Campus and Mukah campus in UiTM, Sarawak Branch was conducted. This was to weigh the institution actions on the sustainability practices. The ten factors were administration with six indicators, recycling and waste with ten indicators, student involvement with five indicators, sustainable water use with two indicators, sustainable transport with five indicators, sustainable building design and renovation with three indicators, green purchasing with four indicators, energy-carbon footprint with one indicator, faculty involvement with three indicators and finally, landscapes and biodiversity with five indicators. The respondents were asked to select accordingly that applied: being followed, not followed, not relevant and needing suggestions.

In addition, a preliminary study on questions was designed to ask about the perception of staff and students as respondents regarding quality of life mainly derived from the six categories of the UI GreenMetric survey (Suwartha and Sari, 2013). The questionnaire consisted of two parts. Part I was designed to collect demographic information of the respondents with questions aimed to ask about the age, gender, status and study level. Part II of the questionnaire was designed to ask respondents regarding Quality of Life (QOL) and about aspects related to green campus. One question on the perception of a healthy physical environment was rated with a Likert scale from $0-5$ (not at all to extremely). Eleven questions were on aspects of environment and well-being overall quality of life on campus to be rated with a Likert scale of 1-5 (Strongly disagree to strongly agree). Four questions focused on satisfaction level of environment sustainability management and practices rated from $0-4$ (very dissatisfied to very satisfied). One question was with rating of 1-10 on satisfaction with overall quality of life on campus and the last question addressed the notion of subjective happiness rated from 1-4 using Likert scale: very happy, quite happy, not very happy or not at all happy and the survey used SurveyMonkey to capture the response of the respondents. The data were analysed using IBM SPSS Version 24 for descriptive statistics.

\section{RESULTS AND DISCUSSION}

Ecology-keeping factors on greening initiatives: Figure 1 shows the radar chart displaying the ecology-keeping factors on greening initiatives weighing the institution actions on the sustainability practices in the three campuses. From overall perspective of the three campuses, faculty involvement performed the best attaining the means score of 5 followed by sustainable water use with means score of above 3.5. Samarahan Campus 1 performed best compared than the other two campuses by virtue of being the main campus and oldest campus with a strong administrative means score of almost 4. Samarahan Campus 2 being the second newest campus was strongest in sustainable water use, 


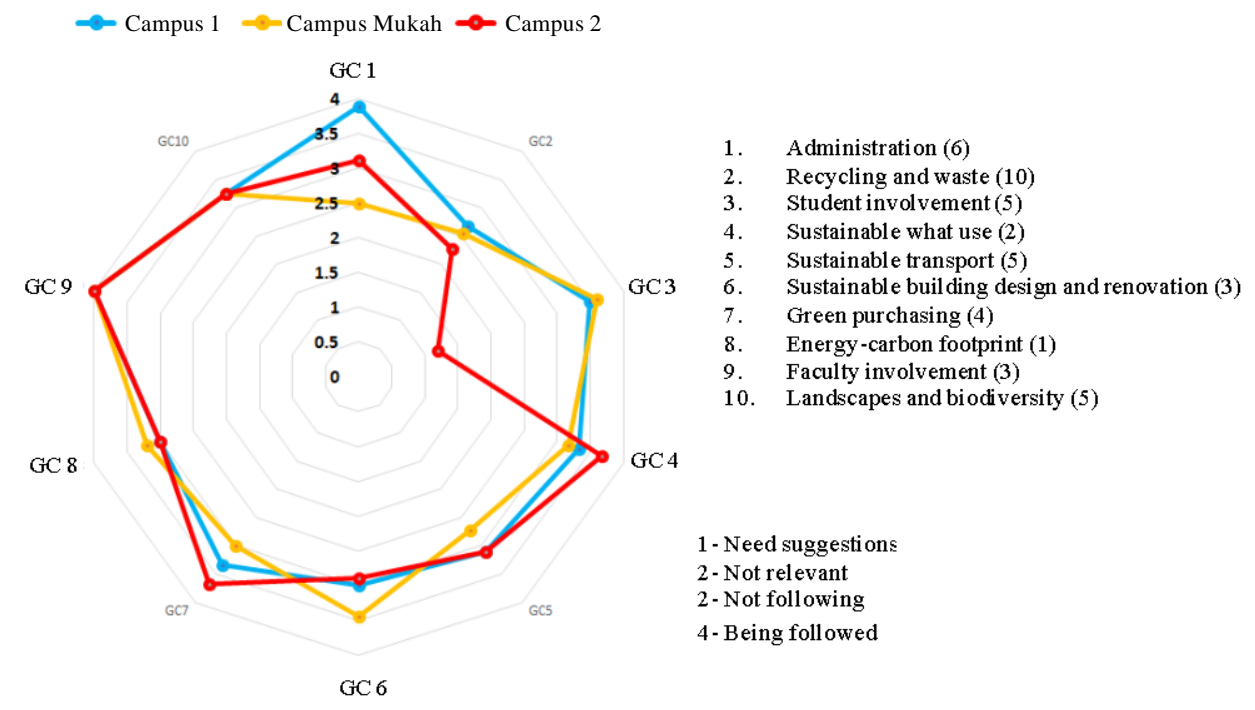

Fig. 1: Average performance rating of indicators of sustainability practices the ecology-keeping factors on greening initiatives in the three campuses: Samarahan campus, Samarahan 2 Campus and Mukah campus in UiTM, Sarawak Branch

sustainable transport, green purchasing and faculty involvement but has the lowest means score of 1.3 in student involvement. Mukah campus being the newest, scores highest among the three in student involvement with means score of above 3.5 , sustainable building design and renovation with means score of 3.5 and energy carbon footprint with means score of above 3. All campuses showed low means score of recycling and waste., an area which should be paid with more attention to encourage this activity. Since, Bogerd et al. (2018) reported that a large body of evidence shows that interaction with greenery can be beneficial for human stress reduction, emotional states and improved cognitive function, the university should also focus on improving landscape and biodiversity which had a combined mean score of above 3 .

Socio-demographic profile of respondents: Table 1 shows the descriptive analysis of demographic characteristics of respondents based gender and category.

Healthy status of the physical environment: Table 2 shows the perception of the respondents from the three campus to the healthy status of the physical environment. In Samarahan Campus 1, majority of the respondent (45.1\%) perceived the physical environment of the campus to be equally either very and extremely healthy. However, in Samarahan Campus 2 and Mukah, majority perceived the physical environment of the campus to be extremely healthy with 58.0 and $74.4 \%$, respectively. Mukah campus being new is a resort campus. Overall,
Table 1: Socio-demographic profile

\begin{tabular}{lrc}
\hline Variables & n-values & Percentage \\
\hline Location & & \\
Samarahan Campus 1 & 156 & 63.9 \\
Samarahan Campus 2 & 49 & 20.1 \\
Mukah Campus & 39 & 16.0 \\
Gender & & \\
Male & 92 & 37.7 \\
Female & 152 & 62.3 \\
Category & & \\
Academic staff & 83 & 34.1 \\
Non academic staff & 35 & 14.3 \\
Students & 126 & 51.6 \\
\hline
\end{tabular}

Table 2: Perception of healthy status of the physical environment of campus

\begin{tabular}{lcccc} 
& \multicolumn{4}{c}{ Rating (\%) } \\
How healthy is the phy sical & -1 & & & \\
environment of the campus & Very little & Somewhat & Very & Extremely \\
\hline Samarahan Campus 1 & 2.0 & 7.7 & 45.1 & 45.1 \\
Samarahan Campus 2 & 0.0 & 8.0 & 34.0 & 58.0 \\
Mukah Campus & 5.1 & 0.0 & 20.5 & 74.4 \\
Overall & 2.0 & 6.6 & 38.9 & 52.5 \\
\hline
\end{tabular}

$52.5 \%$ considered UiTM Sarawak has an extremely healthy campuses. Based on a study by Speake et al. (2013), students perceived green spaces as an essential component of the campus environment as it improved the image of the university.

Aspects of environment and well-being overall quality of life: The Cronbach's alpha of 0.838 revealed that the 10 items had strong internal consistency on aspects of environment and well-being overall quality of life on campus. All respondents from the three campuses agreed that there were QOL and about aspects related to green campus (Table 3) with a combined mean score of 4.1877. 
Table 3: Mean score on perceived QOL based on 10 items with Cronbach's

\begin{tabular}{lcc}
\multicolumn{2}{c}{ alpha of 0.838} & \\
\hline Location & Mean & SD \\
\hline Samarahan 1 & 4.1794 & 0.53618 \\
Samarahan 2 & 4.2780 & 0.43391 \\
Mukah & 4.1051 & 0.62448 \\
Total & 4.1877 & 0.53288 \\
\hline
\end{tabular}

Table 4: Green campus status would be one of selection criteria by university applicant

\begin{tabular}{|c|c|c|}
\hline Location & Mean & SD \\
\hline Samarahan 1 & 3.7935 & 0.91663 \\
\hline Samarahan 2 & 3.8800 & 0.98225 \\
\hline Mukah & 4.0256 & 0.87320 \\
\hline Total & 3.8484 & 0.92383 \\
\hline
\end{tabular}

Table 5: Mean score on satisfaction level of environment sustainability management and practices based on four items with the Cronbach's alpha of 0.728

\begin{tabular}{lcc}
\hline Location & Mean & SD \\
\hline Samarahan 1 & 3.6371 & 0.72423 \\
Samarahan 2 & 3.5700 & 0.71078 \\
Mukah & 3.8782 & 0.73196 \\
Total & 3.6619 & 0.72643 \\
\hline
\end{tabular}

This is supported by McFarland et al. (2008) whose study concluded that undergraduate students deemed green space as a positive impact to their QOL.

Green campus status as one of selection criteria by university applicant: All respondents agreed green campus status would be one of the selection criteria with a mean score of 3.848 , if they were university applicants as shown in Table 4. Mukah campus scored highest mean as expected because it had been branded as a resort campus. As Tiyarattanachai and Hollmann (2016) stated, a green university would increase more positive perception of stakeholders about campus QOL. They added that universities could also use the green campus initiative for marketing purposes for student recruitment. The view was stated by Sisriany and Fatimah (2017) that campus landscape is an important part of campus life because it is regarded as a physical manifestation of the value of a college.

Satisfaction level of environment sustainability management and practices: The Cronbach's alpha of 0.728 indicated that the four items on satisfaction level of environment sustainability management and practices had strong internal consistency (Table 5). The combined mean score respondents were 3.66 indicating satisfaction. A study conducted by Tiyarattanachai and Hollmann (2016) comparing stakeholder's perception about perceived QOL between those in green and non-green campus universities clearly showed that campus better complied with sustainability practices listed in the UI GreenMetric
World University Ranking were more satisfied with sustainability aspects at their campus and have better perceived QOL.

Overall quality of life of campus: Respondents from all three campuses perceived overall quality of life of campus with combined mean score of 8.2 based on a rating of $1-10$ on satisfaction. They were also close to very happy on the notion of subjective happiness as the combined mean score was 3.64. According to MacKerron and Mourato (2013), links between wellbeing and environmental factors are of interest in health, psychology, economics and more widely as part of the setting and infrastructure criterion.

\section{CONCLUSION}

It is therefore, imperative that UiTM as the largest university in Malaysia should ensure more efforts to promote green campus as it is an important part of campus life regarded as a physical manifestation of the value of a university. This case study on UiTM Sarawak examined the green campus status, the strengths and weaknesses in environment sustainability management and practices. There was an indication of high level of involvement in sustainability practices. The community of the three campuses were satisfied with the campus environmental management and recognized its relation to happiness and wellbeing.

\section{REFERENCES}

Alshuwaikhat, H.M. and I. Abubakar, 2008. An integrated approach to achieving campus sustainability: Assessment of the current campus environmental management practices. J. Cleaner Prod., 16: $1777-1785$.

Anonymous, 2015. Mainstreaming the 2030 agenda for sustainable development. United Nations Development Group, ?New York, USA.

Bogerd, N.V.D., S.C. Dijkstra, J.C. Seidell and J. Maas, 2018. Greenery in the university environment: Student's preferences and perceived restoration likelihood. PloS One, 13: 1-19.

Dolan, P. and R. Metcalfe, 2012. Measuring subjective wellbeing: Recommendations on measures for use by national governments. J. Soc. Policy, 41: 409-427.

Escobar-Tello, M.C. and T. Bhamra, 2013. Happiness as a harmonising path for bringing higher education towards sustainability. Environ. Dev. Sustainability, 15: 177-197. 
Grindsted, T. and T. Holm, 2012. Thematic development of declarations on sustainability in higher education. Environ. Econ., 3: 32-40.

Handl, G., 2012. Declaration of the United Nations conference on the human environment (Stockholm Declaration), 1972 and the rio declaration on environment and development, 1992. United Nations Audiovisual Lib. Intl. Law, 1: 1-11.

MacKerron, G. and S. Mourato, 2013. Happiness is greater in natural environments. Global Environ. Change, 23: 992-1000.

McFarland, A.L., T.M. Waliczek and J.M. Zajicek, 2008. The relationship between student use of campus green spaces and perceptions of quality of life. Hort Technol., 18: 232-238.
Sisriany, S. and I.S. Fatimah, 2017. Green campus study by using 10 UNEP's green university toolkit criteria in IPB Dramaga campus. IOP Conf. Series Earth Environ. Sci., 91: 1-8.

Speake, J., S. Edmondson and H. Nawaz, 2013. Everyday encounters with nature: Student's perceptions and use of university campus green spaces. Hum. Geographies J. Stud. Res. Hum. Geogr., 7: 21-31.

Suwartha, N. and R.F. Sari, 2013. Evaluating UI GreenMetric as a tool to support green universities development: Assessment of the year 2011 ranking. J. Cleaner Prod., 61: 46-53.

Tiyarattanachai, R. and N.M. Hollmann, 2016. Green campus initiative and its impacts on quality of life of stakeholders in green and non-green campus universities. Springer Plus, 5: 1-17. 